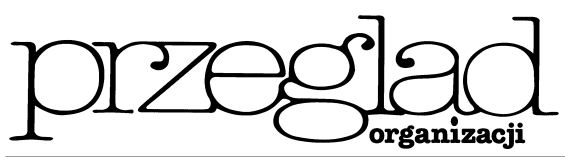

\title{
Relacje między kulturą organizacyjną a strukturą w świetle badań szczecińskich przedsiębiorstw
}

https://doi.org/10.33141/po.2005.06.01

Przegląd Organizacji, Nr 6 (785), 2005, ss. 15-17 www.przegladorganizacji.pl Towarzystwo Naukowe Organizacji i Kierownictwa (TNOiK)

\section{Katarzyna Gadomska, Alberto Lozano Platonoff, Sy/wia Sysko-Romańczuk}

\section{Struktura a kultura organizacyjna przedsiębiorstwa - założenia teoretyczne}

W

literaturze przedmiotu można spotkać dwie konkurencyjne hipotezy dotyczące zależności między kulturą organizacyjną a struktura ${ }^{1)}$.

Hipoteza pierwsza zakłada, że struktura organizacyjna w sposób naturalny i racjonalny reguluje zachowania organizacyjne i nie musi stanowić odpowiedzi na kulturowe uwarunkowania działalności organizacji. Hipoteza druga zakłada natomiast, że struktura organizacyjna jest dostosowywana do kulturowych uwarunkowań funkcjonowania organizacji.

Wyniki badań empirycznych potwierdzające obie wyżej prezentowane hipotezy wskazują na to, że struktura organizacyjna nie zawsze jest odpowiedzią na obowiązujące w przedsiębiorstwach wartości i normy kulturowe. Jeżeli z pewnych względów nie są one brane pod uwage podczas kształtowania struktur, to nie można mówić o strukturotwórczych efektach kultury. Jeżeli jednak są brane pod uwage, wpływ kultury na strukture jest zawsze widoczny. Należy jednak podkreślić, że kultura powinna być traktowana jako czynnik kształtujący strukturę organizacyjną firmy, gdyż stanowi oparcie dla różnych koncepcji struktur organizacyjnych, stwarzając podłoże dla ich skutecznej implementacji i funkcjonowania ${ }^{2}$. Struktura jest wtedy odpowiednia, kiedy ludziom stwarza się warunki skutecznej pracy, co jednak nie będzie możliwe ze strukturą zupełnie obcą kulturowo ${ }^{33}$. Struktura organizacyjna, będąc usankcjonowaniem określonych celów i sposobów postępowania, zapewniającym skuteczne wdrażanie misji przedsiębiorstwa i jego strategii, siłą rzeczy powinna odzwierciedlać cele i zachowania, które są właściwe z punktu widzenia kultury organizacyjnej. Przy braku takiej zgodności przedsiębiorstwo boryka się z dużym obszarem organizacji nieformalnej.

\section{Struktura a kultura organizacyjna przedsiębiorstwa w świetle badań}

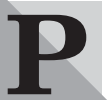

owiązania między strukturą a kulturą organizacyjną przedsiębiorstwa stanowiły jeden z obszarów badawczych objętych analizą w trakcie realizacji przez zespół badawczy Uniwersytetu Szczecińskiego projektu pt. „Diagnoza kultury organizacyjnej przedsiębiorstw" ".). Jego głównym ce- lem była identyfikacja wzorów kulturowych charakterystycznych dla przedsiębiorstw z udziałem kapitalu zagranicznego i przedsiębiorstw bez udziału kapitału zagranicznego (umownie nazywanych krajowymi), m.in. w obszarze struktury organizacyjnej. Zebrane informacje zostały następnie skonfrontowane $\mathrm{z}$ wynikami badań prowadzonych $\mathrm{w}$ ramach drugiego projektu pt. „Ogólna diagnoza szczecińskich przedsiębiorstw”. Zakładał on ocenę sprawności procesów zarządzania w szczecińskich podmiotach gospodarczych ( $w$ tym diagnozę i ocenę struktury organizacyjnej), opracowanie wniosków w celu racjonalizacji tych procesów oraz znalezienie skutecznych instrumentów polityki regionalnej stymulujących konkurencyjność regionu ${ }^{5)}$.

W wyniku przeprowadzonych badań stwierdzono, że przedsiębiorstwa krajowe i przedsiębiorstwa z udziałem kapitału zagranicznego przyjmują różne rozwiązania $\mathrm{w}$ zakresie struktur organizacyjnych. Przeprowadzona analiza statystyczna wykazała, że istnieje zależność między formą własności przedsiębiorstwa a typem jego struktury organizacyjnej. Najważniejsze różnice $\mathrm{w}$ zakresie stosowanych rozwiązań strukturalnych przedstawia tabela 1.

Wyniki badań wskazują, że przedsiębiorstwa z udziałem kapitału zagranicznego charakteryzuje większa elastyczność sposobów działania niż przedsiębiorstwa krajowe. Przedkładają elastyczne typy struktur organizacyjnych nad struktury hierarchiczne. W prawie połowie badanych przedsiębiorstw ich funkcjonowanie oparte jest na pracy zespołów zadaniowych. W tym względzie zdecydowanie dominują przedsiębiorstwa z udziałem kapitału holenderskiego. Koncepcja pracy zespołowej, stanowiąc alternatywę wobec wąskiej specjalizacji pracy, pełni jednocześnie funkcje motywacyjną. Szersze spektrum działalności umożliwia zaangażowanie pracowników w większy zakres spraw. Dzięki takiej formie pracy poszczególny pracownik może przełożyć osiągane przez siebie wyniki na rezultaty pracy całego zespołu i przez ten pryzmat analizować ich wpływ na jakość działania całości przedsiębiorstwa. Praca zespołowa oznacza większy zakres samodzielności oraz swobody działania $\mathrm{w}$ granicach określonych przez przełożonych. $\mathrm{Z}$ badań wynika, że w $80 \%$ firm przełożeni często delegują uprawnienia, co oznacza, że swoboda pracowników jest duża. Stworzenie możliwości współdecy- 
Tab. 1. Synteza różnic między przedsiębiorstwami z udziałem kapitału zagranicznego i przedsiębiorstwami krajowymi

\begin{tabular}{|l|l|l|}
\hline \multirow{2}{*}{ Zagadnienie } & \multicolumn{1}{|c|}{ Rodzaj przedsiębiorstw } \\
\cline { 2 - 3 } & \multicolumn{1}{|c|}{ Krajowe } & \multicolumn{1}{|c|}{ Z kapitałem zagranicznym } \\
\hline $\begin{array}{l}\text { Typ struktury } \\
\text { organizacyjnej }\end{array}$ & $\begin{array}{l}\text { Dominacja hierarchicznych typów struktur, opar- } \\
\text { tych na wyraźnie wyodrębnionych komórkach z jed- } \\
\text { noznacznym określeniem zadań, uprawnien i od- } \\
\text { powiedzialności, bądź też wariant pośredni między } \\
\text { hierarchicznym a elastycznym. }\end{array}$ & $\begin{array}{l}\text { Dominacja elastycznych typów struktur, opartych } \\
\text { na pracy zespołowej. }\end{array}$ \\
\hline $\begin{array}{l}\text { Delegowanie } \\
\text { uprawnień } \\
\text { decyzyjnych }\end{array}$ & $\begin{array}{l}\text { Niezbyt częste. Wśród kadry kierowniczej dominu- } \\
\text { je raczej tendencja do skupiania uprawnień decy- } \\
\text { zyjnych we „własnych rękach”. }\end{array}$ & $\begin{array}{l}\text { Częste, co stwarza pracownikom niższych szczebli } \\
\text { szanse współdecydowania i sprzyja zwiększeniu ich } \\
\text { zaangażowania i odpowiedzialności oraz integracji } \\
\text { z przedsiębiorstwem. }\end{array}$ \\
\hline $\begin{array}{l}\text { System } \\
\text { komunikacji }\end{array}$ & $\begin{array}{l}\text { Swobodny przepływ informacji głównie w obrębie } \\
\text { poszczególnych komórek. Koncentracja na tradycyj- } \\
\text { nych środkach przekazu. }\end{array}$ & $\begin{array}{l}\text { Swobodny przepływ informacji wewnattrz całej fir- } \\
\text { my. Stosowanie zróżnicowanych form i narzędzi } \\
\text { przekazu, wykorzystywanie systemów informatycz- } \\
\text { nych. }\end{array}$ \\
\hline $\begin{array}{l}\text { Postrzeganie } \\
\text { zmian }\end{array}$ & $\begin{array}{l}\text { Tendencja do koncentracji na ochronie tego, co już } \\
\text { się pozytywnie sprawdziło. }\end{array}$ & $\begin{array}{l}\text { Traktowanie zmian jako naturalnego elementu } \\
\text { działalności przedsiębiorstwa, nierzadko poszukiwa- } \\
\text { nie zmian. }\end{array}$ \\
\hline
\end{tabular}

Źródło: opracowanie własne.

dowania jest kolejnym elementem sprzyjającym identyfikacji pracowników z wynikami działalności przedsiębiorstwa jako całości, zwiększenia ich zaangażowania i odpowiedzialności.

Większość badanych przedsiębiorstw z udziałem kapitału zagranicznego, bez względu na kraj pochodzenia udziałowców, cechuje decentralizacja i słaba hierarchia przejawiająca się współdecydowaniem, współpracą i wzajemnością. Najwyraźniej widać to $\mathrm{w}$ przedsiębiorstwach $\mathrm{z}$ udziałem kapitału holenderskiego. Jest to zgodne z wynikami badań Ch. Hampdena-Turnera i A. Trompenaarsa, którzy analizując siedem kultur narodowych wskazali właśnie kulture holenderską jako tę o najmniejszym stopniu zhierarchizowania oraz silnej skłonności do egalitaryzmu ${ }^{6)}$.

Przedsiębiorstwa krajowe częściej organizują swoją działalność według konwencji opartej na jasno zarysowanej hierarchii, wyraźnie wyodrebnionych komórkach, z jednoznacznym określeniem zadań, uprawnień i odpowiedzialności. Potwierdza to tendencja kadry kierowniczej tych przedsiębiorstw do koncentracji uprawnień decyzyjnych we „własnych rękach”. W połowie badanych podmiotów raczej rzadko bądź w ogóle nie deleguje się uprawnień. Z badań nad specyfiką polskich przedsiębiorstw ${ }^{7)}$ wynika, że w praktyce polskich firm pojawia się paradoks. Z jednej strony, można zaobserwować wyraźne dążenie do redukowania nierówności (jednak poglądy dotyczace przywilejów zmieniają się w zależności od miejsca zajmowanego w hierarchii; im wyższe miejsce, tym wyższa ich akceptacja). Z drugiej strony, pracownicy wręcz oczekuja wyraźnych wskazówek i jasnego podporządkowania hierarchicznego. W przeciwnym razie czuja się niepewnie. Przejawiają brak samodzielności i lęk przed ponoszeniem ryzyka i odpowiedzialności ${ }^{8)}$.

Jednakże z badań przeprowadzonych przez autorów wynika również, że dość liczna (40\%) grupa przedsiębiorstw zdecydowała się na wariant pośredni między ścisłą hierarchią a elastycznymi zespołami, a są i takie, które swoje funkcjonowanie postrzegają w kontekście pracy zespołowej. Takie podejście wiąże się z koniecznością przynajmniej częściowego dzielenia się przez przełożonych uprawnieniami i oznacza zwiększoną partycypację pracowników. Stanowi to szansę szybszego adaptowania się do zachodzących zmian, których dynamika niejako zmusza do przyjmowania bardziej elastycznych rozwiązań.

Preferencje przedsiębiorstw w stosowaniu różnych typów struktur organizacyjnych przedstawia tabela 2 .

Typ struktury organizacyjnej determinuje także reakcje przedsiębiorstwa (ich szybkość i rodzaj) na zachodzące $\mathrm{w}$ otoczeniu zmiany. Przedsiębiorstwa z udziałem kapitału zagranicznego, które zmiany traktują raczej jako naturalny element wpisany niejako w charakterystykę swojej działalności, wybierają taki typ struktury, który pozwoli antycypować przyszłe zmiany badź też skutecznie adaptować sie do już zaszłych zmian. Postawa pracowników tych przedsiębiorstw, którzy raczej starają się dostosować do zmian niż je bojkotować, znacznie ułatwia takie reakcje przedsiębiorstw. Zarówno przedsiębiorstwa krajowe, jak i z udziałem kapitału zagranicznego prezentuja podobną postawę wobec zmian, traktując je jako naturalną kolej rzeczy.

W przedsiębiorstwach krajowych pracownicy jeszcze rzadziej przyjmują postawę zachowawczą. Zapewne $\mathrm{w}$ dużej mierze jest to związane $\mathrm{z}$ obecna sytuacja na rynku pracy. W trosce o zachowanie miejsca pracy akceptują stawiane im wymagania, a często także zdając sobie sprawę z nieuchronności zmian - traktują je jako rzecz naturalną. Z drugiej jednak strony, obawa przed utrata stanowiska pracy stanowi najczęstszy powód stawiania oporów przeciw zmianom, które w tym przypadku są postrzegane przez pracowników jako zagrożenie ciągłości ich zatrudnienia. Można to jednak wytłumaczyć głębokim przywiązaniem do pracy w macierzystych komórkach oraz silna identyfikacja z przedsiębiorstwem, na co także wskazują wyniki przeprowadzonych badań.

Skuteczne działanie pracowników oraz ich zadowolenie w dużej mierze zależy od tego, czy stworzy im się odpowiednie warunki realizacji powierzonych zadań, oraz czy odpowiednio zaangażuje się ich w proces podejmowania decyzji. Rozwiązania dotyczące struktury organizacyjnej będą miały na to zasadniczy wpływ. Typ struktury organizacyjnej będzie determinował rodzaj i charakter pracy w przedsiębiorstwie. Aby zaprojektować odpowiednią strukturę organizacyjną bądź tė 
Tab. 2. Charakterystyka struktury organizacyjnej

\begin{tabular}{|l|c|c|c|c|c|c|}
\hline & $\begin{array}{c}\text { Przedsię- } \\
\text { biorstwa } \\
\text { krajowe }\end{array}$ & \multicolumn{3}{|c|}{ Przedsiębiorstwa z udziałem kapitału zagranicznego } \\
\cline { 2 - 7 } & Ogółem & Ogółem & Niemieckiego & Szwedzkiego & Holenderskiego & Innego \\
\hline Liczba odpowiadających firm & $\mathbf{7 5}$ & $\mathbf{7 5}$ & 24 & 21 & 15 & 15 \\
\hline $\begin{array}{l}\text { Hierarchiczna, oparta na wyraź- } \\
\text { nie wyodrębnionych komórkach }\end{array}$ & $\mathbf{4 3 \%}$ & $\mathbf{2 3 \%}$ & $29 \%$ & $14 \%$ & $0 \%$ & $47 \%$ \\
\hline $\begin{array}{l}\text { Elastyczna, oparta na pracy } \\
\text { zespołowej }\end{array}$ & $\mathbf{1 7 \%}$ & $\mathbf{4 5 \%}$ & $46 \%$ & $48 \%$ & $73 \%$ & $13 \%$ \\
\hline Wariant pośredni & $\mathbf{4 0 \%}$ & $\mathbf{3 2 \%}$ & $25 \%$ & $38 \%$ & $27 \%$ & $40 \%$ \\
\hline
\end{tabular}

Źródło: opracowanie własne na podstawie wyników badań.

usprawnić już istniejąca, należy: dokładnie opisać lub też zweryfikować dotychczasowe opisy stanowisk organizacyjnych celem prowadzenia polityki kadrowej skutkującej ,zatrudnieniem odpowiednich ludzi na stanowiskach"; delegować uprawnienia decyzyjne celem zbliżenia decydentów do miejsc powstawania problemów, co ułatwia szybszą reakcję na ich pojawianie się oraz skuteczniejsze wprowadzanie zmian; częściej organizować pracę zespołową stwarzającą szansę na ujawnienie się efektu synergicznego oraz umożliwiająca zdobywanie nowej wiedzy i dzielenie się dotychczasowymi doświadczeniami. Zalecenia te dotyczą przede wszystkim przedsiębiorstw krajowych.

\section{Podsumowanie}

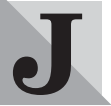

ak wynika z zaprezentowanych wyników badań, kultura organizacyjna może determinować przyjmowanie określonych rozwiązań organizacyjnych, ale gdy sytuacja tego wymaga, struktura może zawierać odpowiednie bodźce motywujące do zmiany nieodpowiednich zachowań, czyli modyfikacji tych wyróżników kultury, które ograniczaja sprawność procesów zarządzania. Bardzo istotną rolę w tym procesie odgrywa kadra kierownicza. Jest to rola pośrednika, który z jednej strony może wpływać na odpowiednie ukształtowanie struktury formalnej, a z drugiej - starać się upowszechniać właściwe wzorce zachowań.

Jeżeli przedsiębiorstwa maja szybko reagować na zmiany zachodzace $\mathrm{w}$ otoczeniu, muszą przekazać więcej odpowiedzialności, władzy i informacji osobom znajdującym się najbliżej tych komponentów otoczenia, które mają największy wpływ na skuteczność ich działania, czyli głównie klientów i kooperantów. Nierzadko wiąże się to ze zmianami istniejacych dotychczas rozwiązań strukturalnych. Oznacza to z kolei wzrost znaczenia obowiazujacej wszystkich pracowników hierarchii wartości. W sytuacji wprowadzenia tego typu zmian w strukturze organizacyjnej sterowanie i kontrola są sprawowane bardziej elastycznie, gdyż podstawową funkcję kontrolną pełni uznawana hierarchia wartości. Wspólne wartości powodują, że kierownictwo i pracownicy posługują się tym samym językiem i realizują tę samą koncepcję działania. Rola kadry kierowniczej sprowadza się do ustalania parametrów, które służą do oceny pracy oraz stosowania zachęt (materialnych i niematerialnych) do przejawiania inicjatywy ${ }^{9}$. Taka sytuacja oznacza, że w przedsiębiorstwach celem zwiększenia elastyczności i sprawności ich działania może zaistnieć konieczność jedno- czesnego dostosowywania się kultury i struktury organizacyjnej.

dr Katarzyna Gadomska, dr inż. Alberto Lozano Platonoff, dr Sylwia Sysko-Romańczuk

Katedra Organizacji i Zarządzania

Wydziału Nauk Ekonomicznych i Zarządzania Uniwersytetu Szczecińskiego

\section{PRZYPISY}

1) M. CIURLA, M. HOPEJ, Kultura a struktura organizacyjna, "Przeglad Organizacji” 1994, nr 4, s. 11.

2) Por. A."PIOTROWICZ, Czynniki określajace strukture or ganizacyjna przedsiebiorstwa, „Ekonomika i Organizacja Przedsiębiorstwa" 2002, nr 3, s. 8.

3) Fakt ten jest również podkreślany w: H.J. WARNECKE, Rewolucja kultury przedsiebiorstwa. Przedsiebiorstwo fraktalne, Wydawnictwo Naukowe PWN, Warszawa 1999 s. 43 .

4) Badania trwały od maja do listopada $2001 \mathrm{r}$. Kwestionariusz ankietowy skierowano do naczelnej kadry kierowniczej, gdyż w zasadniczej mierze to ona kształtuje i utrwala wzory kulturowe oraz wytycza kierunki zmian kultury organizacyjnej i, mimo nierzadko dużej rotacji pracowników na niższych stanowiskach, pozwala na dłużej zachować przyjęte rozwiązania i sposoby działania. W efekcie uzyskano zwrot wypełnionych kwestionariuszy ankietowych ze 150 przedsiebiorstw ( 75 z udziałem kapitału zagranicznego i 75 krajowych) spośród 280 zaproszonych do wzięcia udziału w badaniach.

5) Badania zostały podzielone na dwa etapy. W pierwszym, od listopada 2000 do listopada 2001, poddano badaniu 688 przedsiębiorstw za pomocą dwóch rodzajów ankiet - małej, liczącej 50 pytań, dla firm mikro (zatrudniających do 9 osób) i dużej, liczacej 99 pytań, dla pozostałych podmiotów. Przygotowano także suplement dla firm prowadzacych działalność eksportową. Wyniki ankiet zostały wsparte informacjami uzyskanymi w trakcie spotkań i wywiadów z kadra kierownicza. W drugim etapie, od stycznia 2002 r., prowadzone są szczegółowe przeglądy firm (do maja 2002 r. wykonano ich 50).

6) Ch. HAMPDEN-TURNER, A. TROMPENAARS, Siedem kultur kapitalizmu, Dom Wydawniczy ABC, Warszawa 1998 , s. 240

7) Mowa o badaniach wstępnych prowadzonych w ramach polsko-niemieckiego programu badawczego (Wirtschaftsund Unternehmungsentwicklung in der deutsch-polnischen Grenzregionen im Prozeß der EU-Integrations Polen) - Polskie i rosyjskie przedsiębiorstwa $w$ okresie transformacji gospodarki, redakcja naukowa K. KRZAKIEWICZ, B.Z. MILNER, Akademia Ekonomiczna w Poznaniu, Poznań 2001, s. 105.

8) Na taka postawe pracowników polskich przedsiebiorstw wskazuja również wyniki badań przeprowadzonych przez A. Glińską-Neweś. Por. A. GLINSKA-NEWES, Tendencje $w$ ewolucji kultur organizacyjnych polskich przedsiębiorstw na tle wyzwań globalizujacego sie otoczenia, „Przeglad Organizacji” 2001, nr 7-8, s. 9-12.

9) R. HOWARD, Values Make the Company. An Interview with R. Haas, Harvard Business Review " 1990, nr XXI, za: W. STRASZYNSKI, Znaczenie ogólnie uznanych wartości, „Przegląd Organizacji” 1991, nr 5, s. 34. 